This article was downloaded by: [Damian González]

On: 22 April 2013, At: 08:31

Publisher: Routledge

Informa Ltd Registered in England and Wales Registered Number: 1072954 Registered office: Mortimer House, 37-41 Mortimer Street, London W1T 3J H, UK

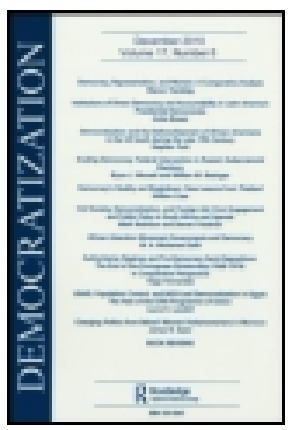

\title{
Democratization
}

Publication details, including instructions for authors and subscription information:

http:/ / www. tandfonline.com/loi/ fdem20

\section{The social factory of democracy in underdeveloped Spain}

\author{
Oscar Martin Garcia ${ }^{a}$ \& Damian González Madrid ${ }^{b}$ \\ a Institute of History, National Council for Scientific \\ Research, Madrid, Spain \\ ${ }^{b}$ Department of History, University of Castilla-La \\ Mancha, Albacete, Spain \\ Version of record first published: 20 Apr 2013.
}

To cite this article: Oscar Martin Garcia \& Damian González Madrid (2013):

The social factory of democracy in underdeveloped Spain, Democratization, DOI: 10. 1080/ 13510347.2013.781587

To link to this article: http:// dx. doi.org/ 10.1080/ 13510347.2013.781587

\section{PLEASE SCROLL DOWN FOR ARTICLE}

Full terms and conditions of use: http://www.tandfonline.com/page/termsand-conditions

This article may be used for research, teaching, and private study purposes. Any substantial or systematic reproduction, redistribution, reselling, loan, sublicensing, systematic supply, or distribution in any form to anyone is expressly forbidden.

The publisher does not give any warranty express or implied or make any representation that the contents will be complete or accurate or up to date. The accuracy of any instructions, formulae, and drug doses should be independently verified with primary sources. The publisher shall not be liable for any loss, actions, claims, proceedings, demand, or costs or damages whatsoever or howsoever caused arising directly or indirectly in connection with or arising out of the use of this material. 


\title{
The social factory of democracy in underdeveloped Spain ${ }^{1}$
}

\author{
Oscar Martin Garcia ${ }^{\mathrm{a} *}$ and Damian González Madrid ${ }^{\mathrm{b}}$ \\ ${ }^{a}$ Institute of History, National Council for Scientific Research, Madrid, Spain; ${ }^{b}$ Department \\ of History, University of Castilla-La Mancha, Albacete, Spain
}

(Received 25 July 2012; final version received 13 February 2013)

\begin{abstract}
This article aims to analyse the contribution made by Christian movements towards constructing a democratic citizenship in an authoritarian context in the backward province of Albacete. Our study attempts to analyse the efforts made by grassroots Catholic sectors to foster democratic enclaves free from the interference of the Francoist state in 1960s and 1970s Spain. These alternative social spaces enabled new habits of civil resistance that confronted the socio-cultural hegemony of authoritarian values. As a result, throughout these years, various social groups started to challenge the sense of the regime's impregnable unity. This grassroots experience with the "power of the powerless" laid the foundations for negotiations among the political elites during the transition to democracy in Spain.
\end{abstract}

Keywords: dictatorship; democratic citizenship; Catholic mobilization; civil society; civic resistance

\section{Introduction}

This article aims to analyse the contribution made by Christian movements towards constructing a democratic citizenship in an authoritarian context in the backward province of Albacete. Our study attempts to analyse the efforts made by grassroots Catholic sectors - generally in collaboration with communist activists to foster democratic enclaves free from the interference of the Francoist state in 1960s and 1970s Spain. ${ }^{2}$ These democratic enclaves enabled a wide range of civic, political and non-violent activities that confronted the sociocultural hegemony of authoritarian values. In other words, a "parallel polis" was created at the heart of the Catholic networks of sociability, which progressively contributed towards undermining the dictatorship's sources of legitimacy at the local level. As a result, throughout these years, various social groups started to explore new habits of civil resistance, to experiment with the "power of the powerless" and to challenge the sense of the regime's impregnable unity. ${ }^{3}$

The following pages endeavour to demonstrate that in the late Franco regime, the underdeveloped provinces of Spain witnessed the emergence of peaceful practices of "people power". These new collective repertoires expanded the

*Corresponding author. Email: Oscar.Martin@cchs.csic.es 
margins for greater citizen participation in public affairs in regions of the country which had the lowest levels of social mobilization. This process laid the foundations for negotiations among the political elites during the transition to democracy. ${ }^{4}$ But what does this article contribute to the research on civil society and the third wave of global democratization studies?

Its main aim is to add the Spanish case to the bibliography on the subject. It is a case which has received little attention but is important for various reasons. First, the construction of democratic citizenship analysed below followed similar lines compared to processes in Central and Eastern Europe. The latter have given rise to most of the literature on civil society and the "anti-authoritarian tsunami" that took place in different parts of the world between 1974 and 1990. This approach to the term of "civil society" as the representation of "people power" has featured prominently in the poetry, tactics and research on the post-communist revolutions. In fact, it was not until the fall of state socialism in Europe that social sciences, encouraged by the optimism of the West's victory in the Cold War, again took up the research on the relationship between civil society and self-liberation.

However, the Spanish case highlights the fact that this concept of civil society was not reinvented in the 1980 s by anti-communist movements. Albeit without the theoretical base subsequently developed by intellectuals such as Michnik, Kuron or Havel, experiences of civic autonomy under autocratic systems already existed in 1960s Spain. ${ }^{5}$ This chronological factor places the resurrection of an alternative public sphere in the Iberian country in a different international scenario, to which the literature has paid little attention. Nevertheless, as Garton Ash points out, the national chapters of non-violent defiance to political oppression from the late 1940 s to 1990 s were highly influenced by the so-called "Global Cold War". 6

But the effects of this bipolar international arena on domestic anti-authoritarian resistance varied over time. In other words, they experienced different historical situations, with the subsequent theoretical implications on the literature on the third wave of democratization. This work underscores some explanatory shortcomings of the "model wave" that, within the same rigid framework, encompasses complex mechanisms developed under different geopolitical circumstances. For instance, the replacement of the Latin-American caudillos and the European communist regimes happened in an international context favourable to democratization. However, the reconstruction of Spanish civil society occurred in an external environment hostile to political experiments. In fact, this article shows that the liberation of everyday life at the local level is also possible when democracy is undergoing difficulties in the global system.

Second, this research examines how certain groups of the Spanish Catholic Church helped to create a civil society that eroded the sociocultural basis of Franco's power. This is not a novel topic in the research on democratization. However, it is of interest because in the regime changes of the 1970s and 1980s there were perhaps no cases in which relations between the church and the state were as close as they were in Franco's Spain. There was a symbiosis between spiritual and temporal power which meant that the Second Vatican Council received a 
particular reception in Spain. It is important to take this into consideration when analysing relations between Catholic mobilization and political transformation.

Third, this article asks whether, in the context of a dictatorship, it is possible for democratizing processes to develop in backward provinces. This would appear to be a pertinent question because influential modernization theories consider that underdeveloped regions are genetically unfit for democracy. In fact, this is often an object of study passed over by a social theory which, as Keane points out, has traditionally established close links between democratization and westernstyle modernization. ${ }^{7}$ Structural conditions are certainly important. However, this article attempts to demonstrate that civil society can flourish in unfavourable international contexts regardless of a particular region's economic conditions.

Finally, the reconstruction of civil society in the third wave of democratizations has in most cases been studied from the viewpoint of sociology and political science. In this respect, there have been many comparative studies based on secondary sources. By contrast, there have been fewer studies from a historiographical perspective. However, this article takes microhistory as a means of applying general questions to specific social processes. In order to do this, a wide range of archive sources have been examined in an attempt to acquire more detailed knowledge of the specific complexities in which the civil society emerged in one Spanish province. The documentary material brings us closer to the micromobilization mechanisms. Moreover, the oral sources used here represent an essential tool in order to obtain a deeper knowledge of the silent processes, hidden in the everyday comings and goings of civil society.

\section{Why the Spanish case?}

The literature on the third wave of global democratization has included various works on the rediscovery of the concept of civil society in terms of political emancipation. These studies have traced the reinvention of this version of civil society back to late 1970s communist Europe. Thus, the democratic revolutions in Central and Eastern Europe have become the paradigm of the relationship between civil society's self-liberation and democratization. ${ }^{8}$ This theoretical approach has later been discussed in a variety of research on regime changes in Latin America, Asia and Africa. But the debate has not generally included the Iberian transitions, precisely the starting point of this democratizing tsunami. ${ }^{9}$

The oversight of the Spanish case may be related to the constant presentation of the post-Franco transition as "the very model of the modern elite settlement". 10 During the last three decades various contributions have highlighted the important role played by social movements in the emergence of democracy in this country. ${ }^{11}$ But their conclusions have only been very gradually incorporated into the theoretical debate. The discussion on Spanish democratization is still heavily influenced by "transitology". Yet this theory does not pay too much attention to the capacity for agency from civil society organizations. ${ }^{12}$ However, the analysis of the resurrection of civil society in Spain is important. As we shall attempt to demonstrate 
below, experiences of civic resistance existed in this part of Iberia prior to the appearance of movements such as Solidarity or Charter 77 in Central Europe. An alternative civil society grew up in 1960s and early 1970s Spain even before the global cycle of democratizations started. It means the "third wave" model has homogenized this case into a comparative framework that obscures the social fabric of Spanish democracy.

From the end of the 1970 s, the reinvention of civil society in communist Europe was aided by the conformation of a new international situation. According to Huntington, external factors (such as the commitment made by US administrations from the late 1970s onwards to promote human rights or the subsequent "lifting of the Soviet imperial constraints") shaped an international climate favourable to democratization. ${ }^{13}$ However, the enclaves of peaceful disobedience previously developed in Spain appeared in a global context in which democracy was generally in recession. Such civil networks were expanded in the 1960s and the early 1970s in a situation which was particularly bad "for political freedom and human rights in the world". ${ }^{14}$ In the middle of the Cold War, the authoritarian wave which spread between 1961 and 1975 gave rise to international pessimism about the strength of Western democracy. At the same time, the social uprisings of 1968 and the economic crisis (1973) eroded faith in the liberal political principles on which post-war Europe had been built. ${ }^{15}$

In this turbulent context, it is hardly surprising that the major powers viewed the processes of civil resistance with great suspicion. In Washington and Moscow they were perceived as risky experiments with unforeseeable consequences for the unstable international status quo of the time. ${ }^{16}$ In fact, the détente promoted by the USA and the USSR aimed to strengthen the bipolar disciplinary structure weakened by the countercultural uprisings of the 1960s. ${ }^{17}$ However, as we shall see below, such unfavourable geopolitical conditions did not prevent a new civil society appearing in Spain at the end of the Franco regime.

Some authors consider that another factor which drove the third wave was the democratic commitment of the Catholic Church following the Second Vatican Council. In this respect, the role of the Catholic Church is well known in communist countries such as Poland. However, the considerable privileges enjoyed by the Catholic Church during the Franco regime had little to do with the religious repression suffered by Catholic activists in Central and Eastern Europe. ${ }^{18}$ The Spanish case appears to bear a closer resemblance to Latin American cases. However, in none of these countries was the symbiosis between religious and political power as strong as in Spain, where the church never broke its links with the Franco regime. ${ }^{19}$

The Spanish church justified General Franco's coup d'état which led to civil war in 1936 as a crusade against communism. After that bloody struggle, the church became part of the victorious new authoritarian state, constituting one of the fundamental pillars of despotic power together with the army and the single party. That is why the Second Vatican Council had a greater destabilizing effect on the Spanish dictatorship than on other similar regimes. The new council 
doctrines clashed head-on with the Catholic self-definition of the Franco state itself, causing major internal ruptures within the Spanish church. It was divided with confrontations between: (1) the old guard of bishops loyal to Franco, (2) the reformist hierarchies and (3) the younger generations of progressive priests who promoted community movements in defence of the oppressed classes. These groups, which were inspired by the 1968 forms of self-management, played an important role in experiments with new notions of civic participation. ${ }^{20}$

However, the literature on the "third wave" generally presents civil society as a structure to support liberal democracy. Likewise, some studies have correlated peaceful resistance with successful transitions towards western-style democracies. $^{21}$ This type of interpretation does not consider the "people power" as a democratic goal in itself. ${ }^{22}$ However, the militants from Catholic movements in the 1960s viewed citizenship in a different manner, namely as a sphere of self-organization from below, in which the ends were just as important as the means. It is therefore important to recapture that transforming notion which Spanish conciliar movements lent to civil society. It was a concept which gradually disappeared in 1980s democratic Spain as a result of the process of socio-political demobilization.

\section{The forgotten rural regions}

The third wave's historiography has neglected the study of the appearance of civic enclaves in rural areas of democratizing nations. Transition studies in Spain have also shown little interest in those regions of the country which had low levels of socio-economic growth during the 1960s and 1970s. This lack of attention could be due to the lasting influence of the modernization approach on social theory and democratization studies. This long influence has also been deployed on the history of the late Franco regime. As a result, political change in Spain has usually been presented as the inevitable corollary of socio-economic modernization in which the citizens of the backward regions did not play any remarkable role. $^{23}$

This point of view implies that passiveness was the norm in those parts of Spain, such as the province of Albacete. The social and economic structure of Albacete and other provinces of "underdeveloped Spain" was characterized by: (1) an industrial sector dominated by the atomization of typically low technology family businesses; (2) an archaic agricultural sector which was barely mechanized; (3) labour relations based on paternalism and fear; (4) high levels of unemployment and emigration among the poorly qualified working classes; and (5) serious shortages in public equipment and social services. Albacete and other traditionally agricultural regions, such as Jaen, Toledo, Ciudad Real, Cáceres, Salamanca, Soria, Badajoz, Palencia, Teruel, Cuenca, Guadalajara, Cordova, etc., were excluded from the dictatorship's economic development programme. In fact, the economic growth seen in Spain between 1959 and 1975 highlighted regional differences. ${ }^{24}$ During this period, the level of inequality grew between the rich periphery and 
the villages of a poor, under-populated inland plateau. From a modernizing viewpoint, these underdeveloped areas did not fulfil the structural prerequisites needed for the emergence of wide-ranging movements of opposition. ${ }^{25}$

Despite the difficulties, in zones such as Albacete communist groups were in fact present. In this province the Communist Party participated in the workers' protests and encouraged the formation of youth and neighbourhood clubs. The communists also became involved in professional associations (health workers, teachers, lawyers, civil servants, etc.), introduced the cooperative movement and organized the Comisisones Obreras del Campo. However, in general terms, this party's ability to act and the extent to which it was established in these parts of Spain was much less than in the industrial centres of the country. In backward regions, the social vacuum caused by the weakness of the clandestine opposition was filled by Catholic groups, which took advantage of the protection of the Catholic Church. ${ }^{26}$ Here we do not intend to minimize the importance of the role played by church dissidence in the more advanced provinces of the country. Instead, we intend to highlight its vital function in areas where the structural conditions hindered the rise of strong movements opposed to the dictatorship.

As some studies are beginning to show, the effects of the Vatican Council were felt in parts which were not affected by the "Spanish economic miracle". ${ }^{27}$ In this respect, the diocese of Albacete is also a good example of the conflicts experienced by the Spanish Church in these years. Since its creation in 1950 until Franco's death in 1975, this diocese was governed by two moderate bishops. While attempting to maintain good relations with Franco, these bishops tried to adapt the provincial church to the new forms of religiousness as defined by the Vatican Council. However, this tepidly reformist position did not prevent the church hierarchy of Albacete from making an effort to maintain internal order in light of the demands of the progressive priests. These priests demanded: (a) more participation and a change in the structure of authority within the church; (b) a radical review of the church's political role; and (c) a break from the Franco dictatorship. These sectors open to dialogue with non-orthodox Marxism represented a minority within the church in Albacete. They nevertheless managed to create new civic platforms in which a growing number of people started to explore horizontal forms of relationships. ${ }^{28}$

However, the previously mentioned influence of the modernizing paradigm has led social history on 1960s Spain to focus its interest on the worker and student uprisings which attracted greater public attention. As a result, research on the popular anti-Francoist response has centred on the more spectacular demonstrations of discontent. ${ }^{29}$ Thus, in the Spanish case there is only limited research devoted to analysing the strategies of "silent" micro-mobilization at grassroots level. The aim of this kind of subtle action was not to protest in the streets, but rather to construct new spaces of participation and resistance within civil society. ${ }^{30}$ 


\section{Social criticism, popular values and community development}

Between 1966 and 1975, some grassroots apostolic groups, such as the Hermandad Obrera de Acción Católica (HOAC), Juventud Obrera Católica (JOC) and Movimiento Rural de Adultos (MRA), played an important formative role in areas with low levels of industrialization, such as the province of Albacete. ${ }^{31}$ In the late 1960s, a small group of young priests linked to these specialized organizations decided to live out their pastoral commitment in the poor rural setting of the Sierra del Segura. From there, this apostolic movement spread to other areas of the province which were likewise characterized by poverty and emigration. As some of these worker priests recall, the teachings of the Second Vatican Council led the youngest and most socially committed priests to seek "a more authentic dimension of the Gospel". They left the vestry in order to get first-hand experience of the problems of those most in need, of those who "the Church completely turned its back on". Driven by some of the ideas of the new liberation theology, these priests believed that the church's commitment to the weakest required them to "live as the people live", share their experiences and suffer their vicissitudes. ${ }^{32}$

The new priests lived and worked side by side with the seasonal workers. Before setting off for the countryside, these young priests used to organize activities with the workers in the parish facilities. According to police reports, the priests criticized "the authorities, regulations, laws and orders in the hope of enlightening the ignorant". In the villages of Nerpio, Villamalea Fuentealbilla, Elche de la Sierra, Alcaraz, Alcalá del Júcar and surrounding hamlets, meetings of this type were held in 1972 which, according to the Civil Guard, had an "advanced socialist ideology". ${ }^{33}$ Two years later, official reports also stated that in the town of Yeste, some priests were attempting "to attract enemies of the regime among farm labourers". ${ }^{34}$ Meanwhile, the Comisiones Obreras y Campesinas de la Mancha (COC) was created in Villamalea with the participation of communist militants and worker priests. According to Franco's authorities, this organization "acted in conjunction with the Communist Party, at times taking advantage of the friction between the government and the governed with regard to social and economic interests". ${ }^{35}$ The COC transplanted to the countryside the practices of grassroots democracy which arose almost spontaneously from the workers' struggles in the coalfields of the north.

Contact with priests from the MRA led some previously isolated groups of workers to begin frequenting parish groups. The police considered that there was "sufficient reason" to think that the meetings "were not limited to conversations concerning religious matters". ${ }^{36}$ These spaces usually hosted various different activities (ranging from spiritual exercises to afternoon snacks) with which the priests sought to create circles of sociability and break the workers' passivity. Through leisure activities and collective thought, these priests intended to make "the people of the countryside think out loud and get together to think about the political issues which determined their life". ${ }^{37}$ 
Along these lines, one of the aims of the MRA was to promote more critical attitudes among agricultural workers. To that end, it attempted to improve the cultural level through the creation of educational centres, home schools and rural schools such as the Escuela Social Rural in Villarrobledo. The latter operated in a similar way to the Escuela de Hogar y Formación Femenina organized by the JOC in the provincial capital. At the heart of this school, groups of young female workers enjoyed the right to meet and express themselves in a way denied to them by the Franco regime. ${ }^{38}$ In addition, other women from some 15 villages of the province were given the opportunity to "open the mind and the heart beyond the home and the family" by means of Cursos de Cultura Popular. ${ }^{39}$ These were held in the Centro Diocesano de Pastoral Rural-Migrante (CDPRM) in the village of Fuensanta. This social centre had been created by the MRA so that "the people of our villages participate responsibly in civil-political issues" by means of talks, exhibitions, seminars, etc. ${ }^{40}$ The rural Catholic movement endeavoured to make this space a meeting place for the neighbours of the region. It was in fact a place for collective life, in which farmers, core members of the opposition and grassroots Christian groups interacted.

Neither the police nor the authorities liked these types of initiatives. In their opinion, some young priests were inculcating anti-governmental slogans in the day labourers and jeopardizing peace in society. At the end of 1971, the mayor of the town of Nerpio reported a group of priests to the police, accusing them of making it impossible for there to be "understanding between rich and poor". 41 In 1974, leaders of the official pro-Franco trade union also blamed the priests for creating "a climate of strained labour relations". ${ }^{42}$ Other priests were accused of "upsetting the order", of being "libertines" and "communistoids". 43 In January 1977, 21 priests were arrested while they were arguing about trade unionism in the abovementioned pastoral centre in Fuensanta. Officials in places such as Villamalea, Casas Ibáñez, Alcalá del Júcar, El Ballestero and Hellín did everything they could to oust these "red priests" from their villages. ${ }^{44}$

The provincial elites were also upset because priests from the MRA tried to create a more dynamic community life in the villages. These clerics attempted to encourage attitudes of neighbourly collaboration which broke with traditional rural mistrust. The MRA aimed to achieve greater civic cooperation by means of promoting citizens' participation in local festivities. As a Catholic group reported, these had always been organized from above. But in 1969, the priests of Nerpio managed to get the neighbours involved in planning the festivities so that they could be celebrated in a more egalitarian manner. In Liétor, the pressure exerted by local residents, with the support of the priest, managed to organize the most participative festivities ever held in the village. During the festivities in Hellin and Alcalá del Júcar, for the first time ever a stall was set up by a group of Catholics and communists who aimed to provide a "democratic alternative to the village inn" for the working class and peasants". 45

In addition, Catholics and communists were also present in the farming cooperatives of a few villages in the province. It made it possible to establish 
community services in these villages and to promote sociocultural activities diverging from the official discourse. Most of the cooperatives in Albacete were controlled by the only party of the Franco regime. But there were also cases such as the Cooperativa de San Antonio Abad in Vallamalea, the authentic driving force of the economic and social development of this village. During the 1960s, the cooperative, controlled by communist militants backed by the progressive priests, constructed a tightly knit local network of welfare and cultural services. This social structure channelled the local residents' most important social demands, thus contributing towards politicizing a major sector of the population against Franco. It is therefore hardly surprising that this place became known as the "red village". 46

\section{Spaces of freedom and alternative interaction}

During the Franco regime's long period in power, one of its objectives was to replace the public sphere with the official sphere. However, the accelerated modernization which took place during the 1960s made the dictatorship begin to implement new models to integrate forces which emerged as a result of deep social changes. One of the methods used to strengthen the stability of the authoritarian structures and defuse the emergent sociopolitical conflict was to open up new channels of participation. These mechanisms consisted of a law enabling the creation of Asociaciones de Cabezas de Familia (ACF) in 1963, together with the Ley de Asociaciones in 1964. Both laws represented the regime's assumption of a controlled strategic risk in exchange for obtaining greater domestic legitimacy and foreign approval against the backdrop of the erosion of the regime's authority.

The appearance of this new associationism was directly related to official attempts to widen the social base of the regime. But the previously mentioned ACFs were created by the official single party. They were politically and financially controlled by local officials. These bureaucrats tried to establish an ironhanded line of command. This was an attempt to set up a "top-heavy structure" which hindered the participation of all the members. Moreover, whenever an association overstepped its bounds in terms of its ambitions, it was persecuted and declared illegal. However, throughout the 1960s there was gradually less hierarchical supervision due to the lack of resources needed to control the large number of associations created (almost 4000 associations in 1975 with a participation of one million people). ${ }^{47}$

Thus, although it is true that the means of representation in the abovementioned laws were narrow, they nevertheless offered possibilities to increase and diversify the associative phenomenon. In this respect, the new associations contributed towards expanding the dynamics of social response. This does not mean that the mobilization processes which we shall see below were the direct result of the new political opportunities provided by such liberalizing measures. But they 
unintentionally provided citizens with resources which previously did not exist in order to construct more independent civic platforms.

In the province of Albacete, 80 associations were created between 1966 and the first elections of the new democracy in June 1977. The majority of these associations came under close political control. Yet in some cases, such legislation made the public defence of values and interests easier. For this reason, the communists of Villamalea set their sights on the village school's parent-teacher association, which they saw as a tool to "engage in another fight". ${ }^{48}$ Although this group was still subject to official supervision, the communists considered it a valid instrument of action. The party leaders suggested the activists infiltrate the association in order to "cause the administration some problems in our village". 49

The new associative framework provided the political opposition with an opportunity to develop a greater public presence and social imbrication without running the risks involved in operating in secrecy. This was the case of the Club de Amigos de la UNESCO, founded in 1970 by communist militants and Catholic elements. Police reported that this cultural association had been set up by antiFranco groups to act "without the risk of being persecuted for their activities if they did something illegal". ${ }^{50}$ Other similar examples included the Asociación de Antiguos Alumnos de Magisterio, set up in 1975 by Catholics and communists. Its aim was to draw up alternatives in favour of free and democratic education. To use Linz's terminology, these were all "alegal" democratic enclaves: pockets of opposition which were formally legal but ideologically opposed to the dominant discourse. ${ }^{51}$

The new associative legislation facilitated the appearance of small alternative spaces for the interaction of young people. Youths in Albacete were disconnected from the traditional practices of popular sociability which had been destroyed by the Franco regime. But apostolic militants intended to establish relationships with young people who had simply not found a place to spend their leisure time other than the official pro-Franco youth structure. However, from the beginning of the 1970s the Catholic movements promoted new spaces in which groups of youths discovered their ability to organize themselves. ${ }^{52}$ Among others, this was the case of the clubes juveniles in Ossa de Montiel, La Roda, Villarrobledo, Almansa, San Pedro, and Mortero. At the beginning of 1976, the Club de la Juventud in Hellín was created in Catholic circles. Its main aim was to allow young people to organize their own leisure activities by means of music recitals, sports competitions, theatre performances, cinema sessions, etc. Around that same time, a group of students started the Cine-Club Buñuel, which organized cinema forums with a high sociopolitical content. ${ }^{53}$ This tendency gradually eroded the eternal wish of the Franco regime to confine the life of its citizens to the private sphere.

The most active Catholic circles considered that associationism could help to put new energy into youth and community development in rural areas. Conciliar priests believed that youth participation in associative spaces could help to replace the usual passiveness and fatalism of young people from villages. This was the objective of initiatives such as the Catholic youth club Rumbo Joven, 
which aimed to "promote sociability and friendship between young people". ${ }^{44}$ For its part, the Teleclub Parroquial in Tarazona de La Mancha endeavoured to organize itself as an "association of youths gathered together under the same conditions of equality". 55 The purpose of groups of this type was to stimulate a richer and egalitarian youth sociability, in order to transcend the private sphere and move into the abstract terrain of the public good.

For their regular participants, associations and clubs represented "an area of freedom to be together with friends, a place where we feel a little bit free". 56 At that time, such places provided some youths with a meeting point with priests who disagreed with the Franco regime. These clerics "influenced a whole generation of young people" whom they helped to become familiar with democratic customs. $^{57}$ It is therefore no surprise that in 1969 the mayor had blocked the initiation of the Club Parroquial in Yeste for political reasons. The official mistrust was due to the Franco regime's wish to control the boundaries of politics. Years later, similar pressure was put on the Sagato group, whose attempts to edit their own Catholic publication were continually blocked by Franco's governors. These and other bans highlight the conflictive nature of the reconstruction of democratic citizenship, together with its direct struggle with political power. ${ }^{58}$

The abovementioned Sagato group was made up of a handful of young Catholics led by a Marxist priest. They sent articles to the press and held debates on various different subjects. Along the same lines, in 1975 another youth group from Nerpio set out to promote public discussions among their neighbours on subjects which affected the everyday life of the community. They began to distribute a parish leaflet which aimed to be a channel of expression for all the people of the village. Some months later, members of the Teleclub of Alcalá del Júcar also published a leaflet aimed at arousing more critical attitudes among the majority of youths who were "petrified with fear". 59 The dictator's desire to foster feelings of apathy and social distrust started to decline.

\section{Associationism, sociability and democratic citizenship}

From 1966 onwards the Franco regime regulated the voluntary constitution of Asociaciones Familiares de Fines Especificos, which included parent-teacher associations, associations of parents with disabled children, consumer associations, and so on. The most popular associations of this type were parent-teacher associations (PTAs). They increased from 134 in 1971 to 1034 groups registered nationally at the time of Franco's death. ${ }^{60}$ Of the 50 parent-teacher associations which appeared in the province of Albacete between 1966 and 1979, some had the support of politically committed sectors of the church. In particular, the associations in Fuentealbilla, Villamalea and Nerpio were set up with the backing of the MRA. The associations of Letur, Yeste and Pétrola were established under the shelter of the parish churches. The same was true for the three associations created in Villarrobledo between 1975 and 1976, and the association which was legalized in Alcalá del Júcar with the help of the local priest. 
These Catholic parent-teacher associations demanded structural improvements in schools and defended a renovated educational model. In the case of Fuentealbilla, these new educational demands resulted in the promotion of greater "social sensitivity" in the village's educational community. ${ }^{61}$ The aim of another PTA in Hellín was to "constitute the legal representation of pupils' parents (...) so as to be able to be heard by any organisation of the state, province or municipality" in educational matters. ${ }^{62}$ For its part, the association of the Colegio de Ossa de Montiel intended to "legally influence the Public Administration in order to solve the problems related" to their children's education. ${ }^{63}$ These associations attempted to establish themselves as parents' representatives and therefore operate as mediation structures between their demands and the official powers. ${ }^{64}$

Groups of neighbours also tried to establish channels of communication with the municipal governors in order to add their voice to the local political agenda. For instance, one of the main objectives of the Asociación de Vecinos de San Pedro was to "address the public powers in order to inform them of the rightful ambitions of the members and request the adoption of suitable measures" so as to improve the area. ${ }^{65}$ Thus, some family and neighbourhood associations were clearly willing to interact directly with the authorities and to influence public policy. In this respect, these associations created a fertile space for redefining civic identity and citizens' relationship with the state on more democratic terms.

However, this practice of interacting with local political power led the neighbourhood groups to clash with the lack of representation of the authoritarian regime's town councils. One such example of this occurred in summer 1974, when, following several months of fruitless meetings, the residents of San Pedro became aware of the "authorities' limited commitment to our problems". 66 The lack of official attention gradually caused tension between governors and parents and neighbours who were increasingly convinced that the government "was not the same for all its citizens". ${ }^{67}$ As a result, they all gradually increased their criticism of Franco's authorities. In response, the dictatorship obstructed the legalization of the more belligerent neighbourhood and parent-teacher associations. Years later, Catholics recalled that the committed work of various PTAs had led to "suspicion, deception, coercion and persecution at the hands of those who had always been in power in the villages". 68 According to these sources, however, despite such difficulties, the associations "made many parents wake up to the fact that they were actively responsible for the operation of the school". 69 Thanks to their participation in PTAs, a considerable number of parents "realised that many institutions which belonged to them were beyond their control". 70

Just like the parent-teacher associations, neighbourhood groups in the province of Albacete were also linked to a civic movement with a notable presence of Catholic militants. There were often cases like that of the San Isidro group in Almansa, promoted from the parish halls in which the neighbours found a space to meet. ${ }^{71}$ Neighbourhood associationism was already growing and becoming stronger in the province during the period of the transition to democracy, especially between 1977 and 1979. However, its origins and the formation of the first 
organizational endeavours date back to the final years of the dictatorship. That was when the first civic groups began to burgeon around parishes. On working-class housing estates, such as those in San Pedro, Hermanos Falcó and others, residents' demands began with the initiative of a few neighbours backed by the local workerpriest. These peripheral settlers suffered a major lack of public facilities in their neighbourhoods. But the objective conditions did not directly give rise to collective action. This was the result of a deeper process which originated in the creation of informal networks of civic assistance aimed at providing neighbourhoods with basic services. $^{72}$

Social action in the parishes helped to strengthen the incipient networks of mutual assistance. These social links fuelled a certain sense of belonging to a community. They also established horizontal relationship patterns among those neighbours in a similar situation. All these factors helped to arouse an incipient civil society in the neighbourhoods. There was an evolving civic consciousness based on class identity and the sense of social exclusion of those who considered themselves to be "outside the urban area" and "abandoned by the hand of God" 73

As the 1970s progressed, in some neighbourhoods of the city of Albacete a new social meaning of space gradually emerged. This was a counter-hegemonic form of inhabiting the urban environment, in which community cooperation was the alternative to the speculation characteristic of the Francoist model of urban development. Living together in a community governed by the values of trust were some of the ingredients of that civil society. Over the years it gradually took on more elaborate forms of civic cooperation. A good example of this was the Comunidad Parroquial created in 1974 by the local priest and a few residents of the San Pablo neighbourhood, who set up a housing cooperative. This initiative managed to build one hundred houses "aimed at the weakest economic classes". ${ }^{74}$ Collective companies like these (consumer cooperatives, social centres, and so on) made up the cultural genes which shortly afterwards incorporated neighbourhood associations determined to put general civic interests ahead of private services. ${ }^{75}$

By defending civic values in this way, the most active residents of the neighbourhoods also slowly constructed their own vision of the public good. It shifted the focus of attention from more urgent self-help to complaints clarifying citizens' rights. This evolution was noticeable in the discourse of youths from La Vereda, who in March 1976 made it clear to the pro-Franco council members "that we are not asking for charity but rather demanding our rights". ${ }^{76}$ In October the residents of Hermanos Falco made it clear to the local governors that "even though we are poor, we have the right to be attended to". ${ }^{77}$ Although further research is needed in this respect, it appears that the initial pleading tone of the interaction between neighbours and the authorities gave way to more aggressive language based on the concept of social debt to the workers of the neighbourhoods, who had contributed towards generating the wealth of the city and its dominant classes.

Finally, neighbourhood associations introduced new participative forms of democratic organization and language. For example, in the neighbourhood association of San Pedro, any member could "take part and speak and vote freely in the 
general meetings and in the debates" ${ }^{78}$ The statutes of the association of Villamalea included the democratic election of its leaders, decision-making by majority and rendering accounts to members. In the everyday discussions in the association of Hermanos Falcó attempts were also made to ensure that "everyone spoke" and was involved in the decisions. ${ }^{79}$ Active participation in the life of these assembly style social laboratories implied learning about new civic obligations on a daily basis. For those who underwent this experience, living together within these democratic enclaves was a true school of democracy. ${ }^{80}$

\section{Conclusions}

As can be seen in the previous pages, democratic citizenship born in post-Franco Spain was not simply the formal legal result of the pluralist constitution of 1978. It was instead a historical process, the result of a conflictive political struggle which established its roots in the final stage of the Franco regime when there was a qualitative change in the relationship between the state and certain groups of civil society. This transformation was greatly affected by the efforts of grassroots Catholic movements to create democratic enclaves. These spaces were free from the interference of the authorities and enabled the spread of an incipient plural social capital which was independent from Franco's power.

This process was made easier as a result of the political opportunities provided by the new associative framework introduced in the mid-1960s. However, citizenship was present in its own formation process. The relational networks created around the parishes and other centres of sociability helped to spread the narrow limits of the public sphere. The activities carried out in youth clubs, parish halls, associations, and so on, established new civic platforms in which a growing number of people started to explore more horizontal forms of participation. In this way the links, identities and ideas on which the democratic institutions were able to flourish following the death of the dictator were gradually built up on a daily basis.

\section{Notes}

1. Research funded through the research project PII1I09-0270-8598.

2. Our theoretical approach to this topic is based, among others, on Gilley, "Democratic Enclaves in Authoritarian Regimes," 402; McAdam, "Beyond Structural Analysis," 286-9; Held, "Citizenship and Autonomy," 199; Alagappa, "Civil Society and Democratic Change," 479-80; Chandhoke, State and Civil Society, 9; and Young, Inclusion and Democracy.

3. Some of the processes studied here could be analysed from the viewpoint of "civil resistance". This concept helps us set the mechanism for the construction of "people power" dealt with in this article in a more complex theoretical frame. See Randle, Civil Resistance; Roberts and Garton Ash, Civil Resistance and Power Politics; Havel, The Power of the Powerless. The concept of "parallel polis" comes from Roberts, "Introduction," 2-3. 
4. This is also the analytical approach used by Pamela Radcliff in some of her works, such as Radcliff, "Associations and the Social Origins of the Transition."

5. The patterns of Catholic civic resistance in 1960s Spain were connected to the international cycle of protest. Horn, The Spirit of '68, 116-38; Judt, Postwar, 407-8; Eley, Forging Democracy, 348-9.

6. Garton-Ash, "A Century of Civil Resistance," 384-5.

7. This author highlights the accidental, contingent and historical nature of the evolution of the idea of democracy. This leads him to criticize the association between democracy and Western modernity. His theses contrast with development theories. Keane, The Life and Death of Democracy; and Lipset, "Some Social Requisites of Democracy."

8. Bernhard, "Civil Society and Democratic Transition in East Central Europe," 314-18.

9. Although for the Spanish case there are already works which incorporate the notion of an emergent civil society in the transitional period, these contributions, which are quoted throughout this article, are based on Pérez's pioneering work, The Return of Civil Society. Also see Encarnación, The Myth of Civil Society; and Encarnación, "Civil Society and the Consolidation of Democracy in Spain," 53-79; Drake, International Factors in Democratization, 1-2.

10. Gunther, "Spain: The Very Model of the Modern Elite Settlement." For a stimulating alternative vision of this paradigm, see Markoff, Waves of Democracy.

11. This type of approach has come a long way since the initial works of Maravall at the end of the 1970s and Anglo-Saxon Hispanicists such as Balfour, Foweraker, Johnston and Fishman in the early 1990s. They were followed shortly afterwards by the works of Spanish historians such as Molinero, Ysàs and others. See the state of the historiographical question put forward by Balfour and Martín, "Movimientos sociales y transición a la democracia: el caso español," 43-62.

12. Threlfall, "Reassessing the Role of Civil Society Organizations," 937.

13. As a result, between 1976 and 1991 the number of representative systems rose from 39 to 91. Huntington, La tercera ola, 92-8; Rupnik, "Eastern Europe," 115-16.

14. Diamond, "Is the Third Wave of Democratization Over?" 1-2.

15. During those years some authors began to talk of the crisis of Western democracy. See Crozier, Huntington and Watanuki, The Crisis of Democracy.

16. Varsori, "Crisis and Stabilization in Southern Europe during the 1970s," 5-15; Teixeira, The International Politics of Democratization, 2-3.

17. Del Pero, "The United States and the Crises in Southern Europe," 306-7. Also Suri, Power and Protest.

18. Troy, "Catholic Waves of Democratization?" 1093-114; Anderson, "Religion, Politics and International Relations," 383-99; Osa, "Networks in Opposition," 77-104; Lan, "Unfinished Business," 638-9.

19. To this day, the Spanish church has still not condemned the Franco regime, which was established in this country with the support of Hitler and Mussolini. It is the only exception among Western Catholic Churches, which over the last decade have sought forgiveness for their support of Nazism and Fascism. Callahan, La Iglesia católica en España, 389-494.

20. Casanova, La Iglesia de Franco; Alonso, "Children of a Lesser God"; Raguer, Réquiem por la Cristiandad; Maeckelbergh, "The Road to Democracy," 301-32.

21. Karatnycky and Ackerman, How Freedom is Won.

22. Baker, Civil Society and Democratic Theory, and from the same author: Baker, "The Taming of the Idea of Civil Society", 2-7.

23. Townson, Spain Transformed, 10.

24. The economic development model led to a profoundly unbalanced growth in national income. While $54 \%$ of national income was concentrated in $11 \%$ of the country, $53 \%$ 
of the nation received only $14 \%$ of the income. Fundación Foessa, Informe sociológico sobre el cambio social en España, 31-33.

25. González and Martín, "New Players in the Construction of Democracy in Spain," 3968; Herrera, La construcción de la democracia en el campo; Herrera and Markoff, "Rural Movements and the Transition to Democracy in Spain," 455-71; Cobo and Ortega, "La protesta de sólo unos pocos," 113-59. See edition 89 of the journal Ayer, entitled Democracia y mundo rural en España, forthcoming.

26. Archivo Histórico Provincial Albacete (AHPAB), Gobierno Civil (GC), boxes 30553 and 30554. Ortiz, "La Iglesia en una diócesis joven," 235-41.

27. Berzal, Sotanas rebeldes.

28. Ortiz, "La Iglesia en una diócesis joven," 242-64. AHPAB, Organización Sindical (OS), box 2133, Secretariado de Asuntos Económicos (SAE), "Memoria del año 1974."

29. Voss and Williams, "The Local in the Global," 352-77.

30. One of the few exceptions in this respect is Radcliff's interesting monograph, Making Democratic Citizens in Spain.

31. Montero, La Acción Católica y el franquismo.

32. Fresno, Fermento de fe, vida y esperanza, 17-140. The quotes cited come from Seminario de Estudios del Franquismo y la Transición de la Universidad de Castilla-La Mancha (SEFT), oral interviews with Juan Fernández (priest, worker, militant of the neighbourhood movement and leader of the HOAC), Andrés Gómez Beteta (worker-priest), and José Carrión Munera (rural priest), recorded on 5 April 2006, 3 June 2005 and 24 February 2011.

33. AHPAB, GC, box 30554, "Notas Informativas" of the Civil Guard 18 April 1972, 15 July 1972 and 8 December 1972.

34. AHPAB, GC, box 30553, "Nota Confidencial" from the Police Commissioner to the Governor on 30 June 1972. Martín, A tientas con la democracia, 111-16.

35. Archivo Gobierno Civil Albacete, "Memoria del año 1972" (sin clasificar).

36. AHPAB, GC, "Memoria anual del Gobierno Civil, 1971" (book); Archivo de la Juventud Obrera Cristiana - AJOC, Zona Levante-Sureste (ZLS), "Reunión de Zona," box 95, 12 December 1974.

37. La Verdad, 1 May 1975 (newspaper).

38. SEFT, interview with Encarna Calero (member of the JOC and shop steward in the textile industry) recorded on 13 June 2005. SEFT, interview with José Carrión (priest and National Councillor of the MRA between 1977 and 1982), recorded on 8 March 2011; Militante de Apostolado Rural (MAR), 141-42-43 (1979).

39. SEFT, interview with José Carrión on 31 March 2011.

40. MAR, 124 (1976), p. 6.

41. AHPAB, GC, box 30554, "Nota Informativa" of the Civil Guard of 30 November 1971.

42. AHPAB, OS, box 2126, "Memoria anual de 1974" and AHPAB, GC, box 30554, "Nota Informativa" of 21 March 1973.

43. La Verdad, 6 October 1976.

44. AHPAB, OS, box 2145, Secretariado de Asuntos Sociales, "Partes a Madrid," 22 August 1974; AHPAB, GC, box 30554, "Nota Informativa" of the Civil Guard of 30 November 1971, 18 April 1972 and 15 July 1972. SEFT, interview with Antonio Díaz, priest of Nerpio (1965-1970), on 14 April 2011; La Verdad, 14 July 1974, 4 November 1975, 1 February 1977 and 10 August 1977.

45. La Verdad, 1 October 1976.

46. González and Martín, "Desde abajo y en la periferia del desarrollismo," 131-6.

47. Radcliff, Making Democratic Citizens in Spain, 73-5; Ayuso, Las asociaciones familiares, 79-83. 
48. Archivo Histórico Partido Comunista España (AHPCE), Nacionalidades y Regiones (NR), Comité Provincial de Albacete (CPA), box 67, folder 5/3, 1970.

49. AHPAB, GC, box 766, Asociaciones; Ortiz, "Movimientos sociales y sociabilidad," 309-32; AHPCE, NR, CPA, box 67, folder 5/3, 1970.

50. AHPAB, GC, Derechos ciudadanos, Asociaciones, box 764 .

51. Martín, A tientas con la democracia, 239-40; La Verdad, 18 October 1974; Linz, Totalitarian and Authoritarian Regimes, 168-9.

52. AJOC, ZLS, box 95, 4/4, 1975; AHPAB, GC, box 30555, "Nota Informativa" of 27 August 1977.

53. La Verdad, 12 October 1976.

54. AHPAB, GC, box 768, Asociaciones.

55. AHPAB, Delegación Provincial de Juventud, box 28681; La Verdad, 5 December 1976.

56. SEFT, interview with Pepe Tendero (former shop steward and former member of the Communist Party [m-1] and the Joven Guardia Roja) on 23 May 2007.

57. SEFT, interview with Victoria Delicado (former member of the Communist Party [Marxist-Leninist] and the feminist movement) recorded on 14 May 2007.

58. AJOC, ZLS, box 95, folder 2/2, 1975; Jelin, "Citizenship Revisited," 104. Cultural initiatives cut short by officialdom in Martín, A tientas con la democracia, 267-9.

59. The parish leaflet in AHPAB, GC, box 30553; an issue of Teleclubs' "newspaper" in box 30555; see also box 30554, "Notas informativas," 31 December 1973 and 25 June 1974.

60. Ayuso, Las asociaciones familiares en España, 79-83.

61. SEFT, interview with José Carrión on 31 March 2011.

62. The text in inverted commas is translated from the statutes of the parent-teacher associations referred to in the text, all in the registry of associations held in the government offices in Albacete.

63. See also AHPAB, GC, boxes 764-765 and 30058, Asociaciones.

64. Radcliff, Making Democratic Citizens in Spain, 255-6.

65. Statutes of the neighbourhood association from San Pedro y Mortero, 1977, given to SEFT by Antonio Pérez, La Verdad, 28 September 1975.

66. La Verdad, 9 October 1974.

67. La Verdad, 27 June 1975 and 26 October 1976; Radcliff, “Associations and the Social Origins of the Transition," 157-8.

68. Prohibitions in AHPAB, GC, box 30554. Text in inverted commas in Movimiento Rural de Adultos, Aproximación histórica a la vida del Movimiento Rural, 18.

69. Movimiento Rural de Adultos, Aproximación histórica a la vida del Movimiento Rural, 20.

70. MAR, 143 (1979): 11-13.

71. AHPAB, GC, box 765, Asociaciones; AHPAB, GC, box 30554, "Nota Informativa" of 18 November 1977; and Derechos Ciudadanos, 1978-1983, box 30060; SEFT, interviews with Llanos Rabadán (member of the Comunidad de Cristianos de Base El Olivo) on17 February 2011, and with Antonio Díaz (secularized priest) on 14 April 2011.

72. Bordetas, "De la supervivència a la resistència," 66.

73. Hernández, El Cerro del Águila, 80-100; Domènech, "Orígenes. En la protohistoria del movimiento vecinal," 31-33; the text in inverted commas is translated from La Verdad, 9 October 1974.

74. La Verdad, 15 June 1974.

75. Statutes of the neighbourhood association from San Pedro y Mortero, 1977.

76. La Verdad, 20 March 1976. 
77. La Verdad, 26 October 1976; Radcliff, "La ciudadanía y la transición a la democracia," 349. This sort of change in the neighbours' language is also studied in Caprarella and Hernández, "La lucha por la ciudad," 33-53.

78. Statutes of the neighbourhood association from San Pedro y Mortero, 1977.

79. SEFT, interview with Andrés Gómez Beteta on 22 April 2005.

80. Castells, Crisis urbana, 290-1.

\section{Notes on contributors}

Oscar Martin Garcia is Fellow Researcher at the Institute of History of the National Council for Scientific Research (Madrid, Spain). His work has mainly focused on social conflict, civil society and international relations during the late Franco regime and the transition to democracy.

Damian González Madrid is Lecturer at the History Department of the University of Castilla-La Mancha (Albacete, Spain).

The authors' recent research has mainly focused on social movements and the transition to democracy in Spain; their books on this topic include A tientas con la democracia (2008), El franquismo y la transición en España (2008), Claves internacionales de la transición española (2010) and De la cruzada al desenganche: la Iglesia española entre el franquismo y la transición (2011). They have also published academic articles in peer-review journals and contributions in edited volumes dealing with the authoritarian crisis and the rise of social unrest in the Iberian country during the 1960s and 1970s.

\section{Bibliography}

Alagappa, Muthiah. "Civil Society and Democratic Change. An Analytical Framework." In Civil Society and Political Change in Asia. Expanding and Contracting Democratic Space, edited by Muthiah Alagappa, 25-60. Stanford, CA: Stanford University Press, 2004.

Alonso, Gregorio. "Children of a Lesser God. The Political and the Pastoral Action of the Spanish Catholic Church." In The Politics and Memory of the Spanish Transition to Democracy. The Spanish Model, edited by Gregorio Alonso and Diego Muro, 11335. New York: Routledge, 2011.

Anderson, John. "Religion, Politics and International Relations. The Catholic Contribution to Democratization's Third Wave." Cambridge Review of International Affairs 20, no. 3 (2007): 383-99.

Ayuso, Luis. Las asociaciones familiares en España. Madrid: CIS, 2007.

Baker, Gideon. "The Taming of the Idea of Civil Society." Democratization 6, no. 3 (1999): $1-29$.

Baker, Gideon. Civil Society and Democratic Theory: Alternative Voices. London: Routledge, 2002.

Balfour, Sebastian, and Óscar J. Martín, "Movimientos sociales y transición a la democracia: el caso español." In La sociedad española en la transición. Los movimientos sociales en el proceso democratizador, edited by Rafael Quirosa, 4-62. Madrid: Biblioteca Nueva, 2011.

Bernhard, Michael. "Civil Society and Democratic Transition in East Central Europe." Political Science Quarterly 108, no. 2 (1993): 307-26.

Berzal, Enrique. Sotanas rebeldes. Contribución cristiana a la Transición democrática. Valladolid: Diputación, 2007.

Bordetas, Ivan. "De la supervivència a la resitència: la gestació del movimentveïnal a la Catalunya franquista." In Construint la ciutat democrática. El moviment veïnal 
durant el tardofranquisme i la transició, edited by Carme Molinero and Pere Ysàs, 35-112. Barcelona: Icaria, 2010.

Callahan, William. La Iglesia Católica en España (1875-2002). Barcelona: Crítica, 2002.

Caprarella, Marcello, and Fanny Hernández. "La lucha por la ciudad: vecinos-trabajadores en las periferias de Madrid. 1968-1982." In Memoria ciudadana y movimiento vecinal, edited by Vicente Pérez and Pablo Sánchez, 33-53. Madrid: La Catarata, 2008.

Casanova, Julián. La Iglesia de Franco. Barcelona: Crítica, 2001.

Castells, Manuel. Crisis urbana y cambio social. Madrid: Siglo XXI, 1981.

Chandhoke, Neera. State and Civil Society: Explorations in Political Theory. Thousand Oaks, CA: Sage, 1995.

Cobo, Francisco, and Teresa Ortega. "La protesta de sólo unos pocos." Historia Contemporánea. 26, no. 1 (2003): 113-59.

Crozier, Michel, Samuel Huntington, and Joji Watanuki. The Crisis of Democracy. New York: New York University Press, 1975.

Del Pero, Mario. "The United States and the Crises in Southern Europe." In Europe in the International Arena during the 1970s. Entering a Different World, edited by Antonio Varsori and Guia Migani, 301-316. Bruselas: Peter Lang, 2011.

Diamond, Larry. "Is the Third Wave of Democratization Over? An Empirical Assessment." Working Paper 236. Kellogg Institute for International Studies, March 1997.

Domènech, Xavier. "Orígenes. En la protohistoria del movimiento vecinal bajo el franquismo." Historia del Presente 16, no. 2 (2010): 27-41.

Drake, Paul. International Factors in Democratization, 1-61. Madrid: Instituto Juan March, 1994.

Eley, Geoff. Forging Democracy: The History of the Left in Europe, 1850-2000. New York: Oxford University Press, 2002.

Encarnación, Omar. "Civil Society and the Consolidation of Democracy in Spain." Political Science Quarterly 116, no. 1 (2001): 53-79.

Encarnación, Omar. The Myth of Civil Society: Social Capital and Democratic Consolidation in Spain and Brazil. New York: Palgrave, 2003.

Foessa, Fundación. Informe sociológico sobre el cambio social en España (1975-1983). Madrid: Euramérica, 1985.

Fresno, Florencio. Fermento de fe, vida y esperanza en el mundo rural español, 1952-1992. Madrid: Movimiento Rural de Adultos, 2002.

Garton-Ash, Timothy. "A Century of Civil Resistance: Some Lessons and Questions.” In Civil Resistance and Power Politics. The Experience on Non-violent Action from Gandhi to the Present, edited by Adam Roberts and Timothy Garton Ash, 371-90. Oxford: Oxford University Press, 2011.

Gilley, Bruce. "Democratic Enclaves in Authoritarian Regimes." Democratization 17, no. 3 (2010): 389-415.

González, Damián, and Óscar Martín. "Desde abajo y en la periferia del desarrollismo. Cambio político y conflictividad social en La Mancha, 1962-1977." In El franquismo y la transición en España, edited by Damián González, 123-53. Madrid: La Catarata, 2008.

González, Damián, and Óscar Martín. "New Players in the Construction of Democracy in Spain, 1962-1977." Political Power and Social Theory 20 (2009): 39-68.

Gunther, R. "Spain: The Very Model of the Modern Elite Settlement." In Elites and Democratic Consolidation in Latin America and Southern Europe, edited by John Highley and Richard Gunther, 122-44. New York: Cambridge University Press, 1992.

Havel, Vaclav. The Power of the Powerless. London: Hutchinson, 1985.

Held, David. "Citizenship and Autonomy." In Social Theory on Modern Societies, edited by David Held, 162-184. Cambridge: Cambridge University Press, 1989. 
Hernández, Javier. El Cerro del Águila e Hytasa: culturas de trabajo, sociabilidad e imágenes de identificación. Sevilla: Diputación de Sevilla, 1999.

Herrera, Antonio. La construcción de la democracia en el campo (1975-1988). El sindicalismo agrario socialista en la Transición española. Madrid: MAPA, 2011.

Herrera, Antonio, and John Markoff. "Rural Movements and the Transition to Democracy in Spain.” Mobilization 16, no. 4 (2011): 455-71.

Horn, Gerd. The Spirit of '68: Rebellion in Western Europe and North America 1956-1976. Oxford: Oxford University Press, 2007.

Huntington, Samuel. La tercera ola. La democratización a finales del siglo XX. Barcelona: Paidós, 1994.

Jelin, Elisabeth. "Citizenship Revisited: Solidarity, Responsibility and Rights." In Constructing Democracy: Human Rights, Citizenship and Society in Latin America, edited by Elisabeth Jelin and Eric Hersberg, 101-19. Boulder, CO: Westview Press, 1996.

Judt, Tony. Postwar. A History of Europe since 1945. London: William Heinemann, 2005.

Karatnycky, Adrian, and Peter Ackerman. How Freedom is Won: From Civic Resistance to Durable Democracy. New York: Freedom House, 2005.

Keane, John. The Life and Death of Democracy. New York: W.W. Norton and Company, 2009.

Lan, T. Chu. "Unfinished Business: The Catholic Church, Communism and Democratization." Democratization 18, no. 3 (2011): 638-39.

Linz, Juan J. Totalitarian and Authoritarian Regimes. London: Lynne Rienner Publishers, 2000.

Lipset, Seymour. "Some Social Requisites of Democracy: Economic Development and Political Legitimacy." The American Political Science Review 53 (1960): 69-105.

Maeckelbergh, Marianne. "The Road to Democracy: The Political Legacy of 1968." International Review of Social History 56, no. 2 (2011): 301-32.

Markoff, John. Waves of Democracy: Social Movements and Political Change. Thousand Oaks, CA: Sage Publications, 1996.

Martín, Óscar. A tientas con la democracia. Movilización, actitudes y cambio en la provincia de Albacete, 1966-1977. Madrid: La Catarata, 2008.

McAdam, Doug. "Beyond Structural Analysis: Toward a More Dynamic Understanding of Social Movements." In Social Movements and Networks: Relational Approaches to Collective Action, edited by Mario Diani, 281-98. Oxford: Oxford University Press, 2003.

Montero, Feliciano. La Acción Católica en el franquismo. Madrid: UNED, 2000.

Movimiento Rural de Adultos. Aproximación histórica a la vida del Movimiento Rural Cristiano. Madrid: MRA, 1983.

Ortiz, Manuel. "La Iglesia en una diócesis joven." In De la Cruzada al desenganche: la Iglesia española entre el franquismo y la transición, edited by Manuel Ortiz and Damián González, 235-64. Madrid: Sílex, 2011.

Ortiz, Manuel. "Movimientos sociales y sociabilidad en Castilla-La Mancha durante el segundo franquismo." In La España del presente. De la dictadura a la democracia, edited by Abdón Mateos and Ángel Herrerín, 309-32. Madrid: Historia del Presente, 2006.

Osa, Maryjane. "Networks in Opposition: Linking Organizations through Activist in the Polish People's Republic." In Social Movements and Networks: Relational Approaches to Collective Action, edited by Mario Diani, 77-104. Oxford: Oxford University Press, 2003.

Pérez, Víctor. The Return of Civil Society. Cambridge: Harvard University Press, 1993. 
Radcliff, Pamela. "Associations and the Social Origins of the Transition during the Late Franco Regimen." In Spain Transformed. The Late Franco Dictatorship, 1959-1975, edited by Nigel Townson, 140-62. New York: Palgrave, 2007.

Radcliff, Pamela. "La ciudadanía y la transición a la democracia." In De súbditos a ciudadanos. Una historia de la ciudadanía en España, edited by Manuel Pérez, 343-72. Madrid: CEPC, 2007.

Radcliff, Pamela. Making Democratic Citizens in Spain. Civil Society and the Popular Origins of the Transition, 1960-78. New York: Palgrave McMillan, 2011.

Raguer, Hilari. Réquiem por la Cristiandad. El Concilio Vaticano II y su impacto en España. Barcelona: Península, 2006.

Randle, Michael. Civil Resistance. London: Fontana, 1994.

Roberts, Adam. "Introduction." In Civil Resistance and Power Politics. The Experience on Non-violent Action from Gandhi to the Present, edited by Adam Roberts and Timothy Garton Ash, 2-24. Oxford: Oxford University Press, 2011.

Roberts, Adam, and Timothy Garton Ash. Civil Resistance and Power Politics. The Experience on Non-violent Action from Gandhi to the Present. Oxford: Oxford University Press, 2011.

Rupnik, Jacques. "Eastern Europe: The International Context." Journal of Democracy 2 (2000): 115-6.

Suri, Jeremi. Power and Protest: Global Revolution and the Rise of Dètente. Cambridge: Harvard University Press, 2003.

Teixeira, Nuno S. The International Politics of Democratization. Comparative Perspectives. London: Routledge, 2008.

Threlfall, Monica. "Reassessing the Role of Civil Society. Organizations in the Transition to Democracy in Spain." Democratization 15, no. 5 (2008): 930-51.

Townson, Nigel. Spain Transformed. The Late Franco Dictatorship, 1959-1975. New York: Palgrave, 2007.

Troy, Jodok. "Catholic Waves of Democratization? Roman Catholicism and its Potential for Democratization." Democratization 16, no. 6 (2009): 1093-114.

Varsori, Antonio. "Crisis and Stabilization in Southern Europe during the 1970s: Western Strategies, European Instruments." Journal of European Integration History 15, no. 1 (2009): 5-15.

Voss, Kim, and Michelle Williams. "The Local in the Global: Rethinking Social Movements in the New Millennium." Democratization 19, no. 2 (2012): 352-77.

Young, Iris M. Inclusion and Democracy. Oxford: Oxford University Press, 2000. 